\section{Occurrence of Dinodon gammiei (Blanford, 1878) in Sikkim, Eastern Himalaya, India}

\section{Basundhara Chettri ${ }^{1} \&$ S. Bhupathy ${ }^{2}$}

1,2 Sálim Ali Centre for Ornithology and Natural History, Anaikatti (PO), Coimbatore, Tamil Nadu 641108, India

Email: ${ }^{1}$ basundharac@gmail.com; 2 (corresponding author) bhupathy_s@yahoo.com

The Sikkim False Wolf Snake, Dinodon gammiei was first described by Blanford (1878) as Ophites gammiei from four specimens collected from Cinchona plantations near Darjeeling in the British Sikkim. Dinodon is an Indochinese genus having distribution in northeastern India (Smith 1943). Records on the distribution of herpetofauna from adjacent biogeographic realms into India are scarce, and there is need for accurate documentation, reporting and comparisons with museum collections. Dinodon gammiei was known only from Darjeeling Hills making it a highly restricted species until a recent report from Arunachal Pradesh, India (Mistry et al. 2007). Sikkim has no authentic reports of the species. However, it is listed in the reptile fauna of the State (Smith 1943; Waltner 1973; Shaw et al. 1999; Jha \& Thapa 2002; Sanyal et al. 2006). In the Colonial period, Darjeeling Hills were considered as part of the greater Sikkim Himalaya (Gammie 1928). Therefore, the reptile fauna of Sikkim Himalaya was merely derived from that of the Darjeeling Hills. Mistry et al. (2007) even doubted the reported occurrence of this species in Sikkim because there was no specimen in the museum collections known from this state. This report confirms the occurrence of Dinodon gammie $i$ in the northeastern Himalayan state, Sikkim.

In a study on the biodiversity of Teesta valley, Sikkim from 2003 to 2006 four individuals of D. gammiei, one from Toong

Date of online publication 26 January 2009

ISSN 0974-7907 (online) | 0974-7893 (print)

Editor: Karthikeyan Vasudevan

Manuscript details:

Manuscript \# 01960; Received 07 March 2008; Final revised received 16 October 2008; Finally accepted 21 October 2008

Citation: Chettri, B. \& S. Bhupathy (2009). Occurrence of Dinodon gammiei (Blanford, 1878) in Sikkim, Eastern Himalaya, India. Journal of Threatened Taxa 1(1): $60-61$

Copyright: (C) B. Chettri \& S. Bhupathy 2009. Creative Commons Attribution 3.0 Unported License. JoTT allows unrestricted use of this article in any medium for non-profit purposes, reproduction and distribution by providing adequate credit to the authors and the source of publication.

Acknowledgement: We are grateful to the Department of Forests, Environment and Wildlife Management, and Department of Home, Government of Sikkim for permission to carryout this work in the state. We thank the Ministry of Environment and Forests, Government of India and Centre for Interdisciplinary Studies of Mountain and Hill Environment, Delhi University for financial grant. We thank the Director, ZSI for permission to examine specimen deposited at the ZSI museum, Kolkata and to Dr. C.K. Murthy and Mrs. Gouri Dasgupta, Reptilia Section and Dr. Pankaj Bhatnagar, ZSI for help and curatorial assistance. Support of colleagues Bhoj Kumar Acharya, Ranjini, Nikhil and help by Narayan Chettri, and Denchok Lepcha in the field are highly appreciated.

\section{OPEN AGGESS | FREE DOWNLOAD}

$\left(27^{\circ} 32^{\prime} \mathrm{N}-88^{\circ} 38^{\prime} \mathrm{E}\right)$, two individuals from Chungthang $\left(27^{\circ} 36^{\prime} \mathrm{N}-88^{\circ} 38^{\prime} \mathrm{E}\right)$ and one from Khedum $\left(27^{\circ} 37^{\prime} \mathrm{N}-88^{\circ} 42^{\prime} \mathrm{E}\right)$ near Lachung, were recorded. Altitudes above mean sea level (asl) of the localities are 1300,1500 and $2300 m$ respectively. The individuals in

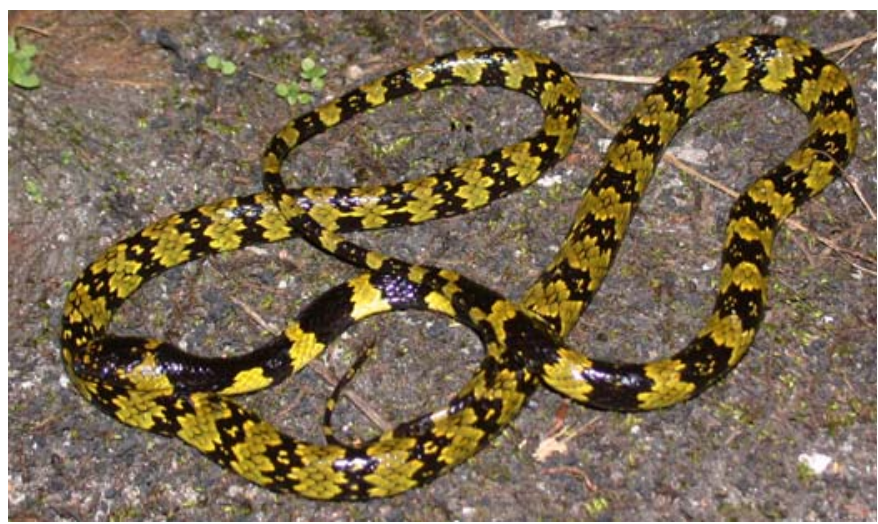

Image 1. Dinodon gammiei (after moulting) observed in Khedum, northern Sikkim

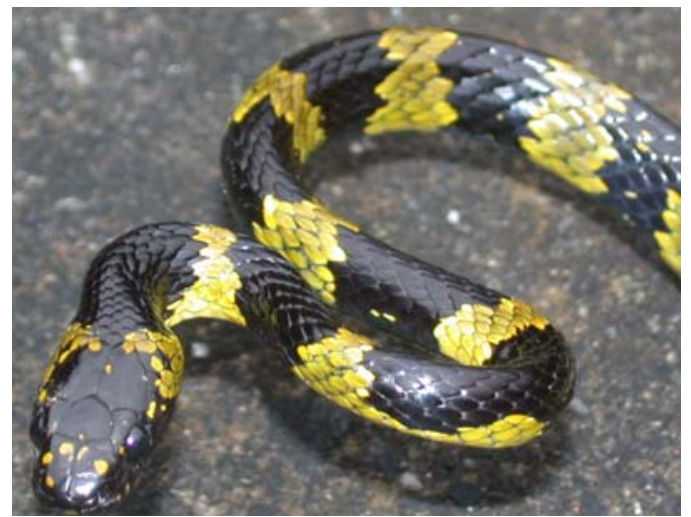

Image 2. Dorsal view of head of Dinodon gammiei from Chungthang, northern Sikkim.

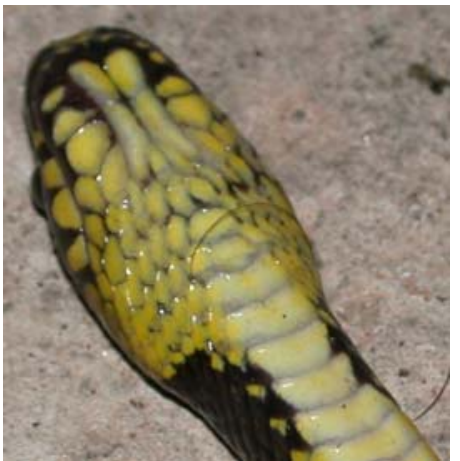

Image 3. Ventral view of the head of Dinodon gammiei from Chungthang, northern Sikkim showing larger posterior genials.

Chungthang were found resting under the roof of a shed in a cardamom plantation, at Khedum, it was found under stone on a steep rocky slope $\left(>45^{\circ}\right)$ and at Toong, it was a road kill. Natural vegetation of the area is tropical-broadleaved forests which have largely been converted into cardamom plantations. Annual rainfall 


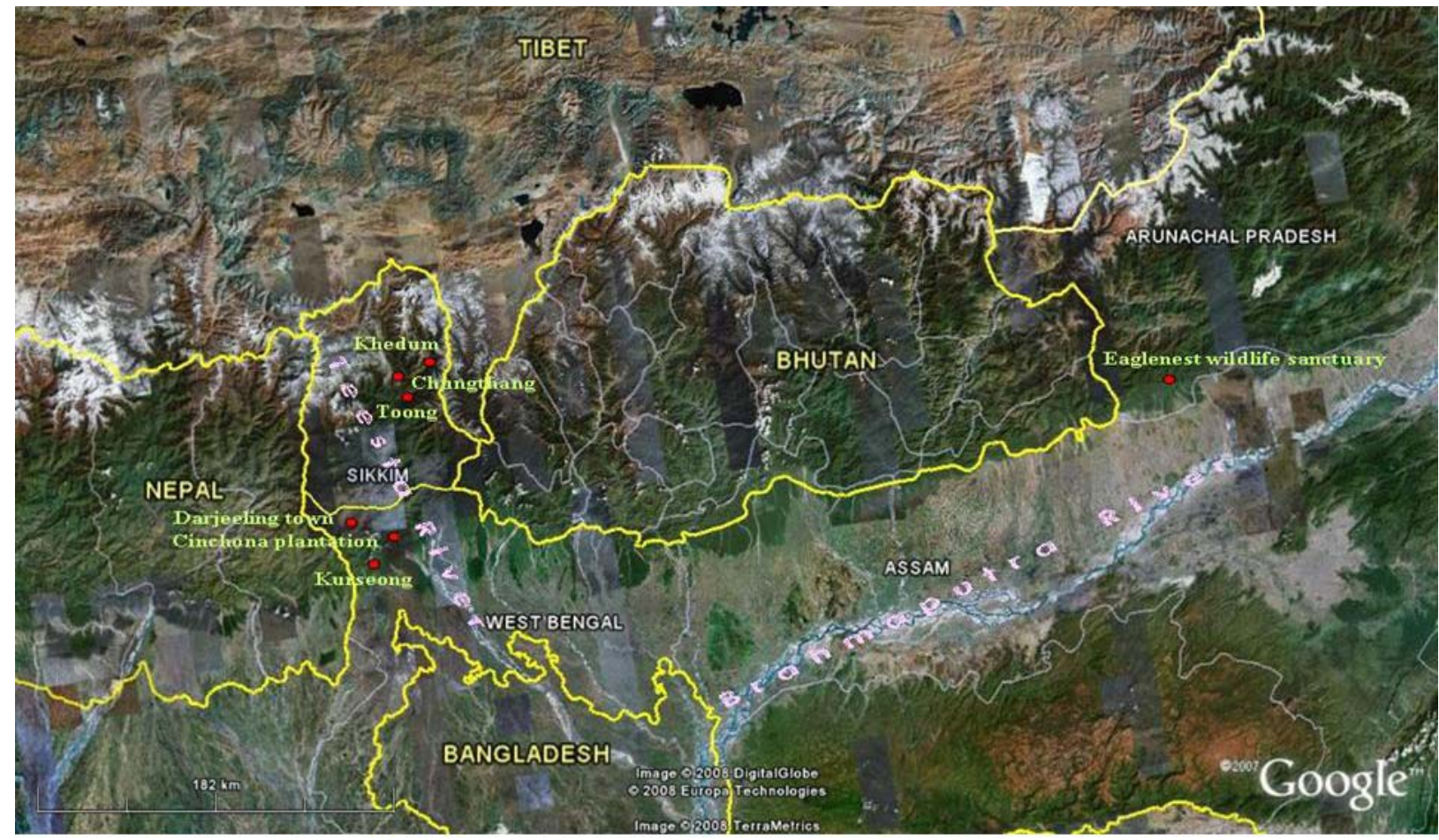

Image 4. Distribution of Dinodon gammiei in northeastern India.

and mean monthly temperature ranges are 1500-2000mm and 9$22^{\circ} \mathrm{C}$ respectively.

Snakes were photographed (Images 1-3) and released in the same area after recording pholidosis and morphometry. Data on morphometry and pholidosis of this species (Mistry et al. 2007) and the specimens from Darjeeling District deposited at Zoological Survey of India, Kolkata (collected by Lord Carmichael, Reg. No. ZSI 17129, Darjeeling, North Bengal) were compared with specimens recorded from Sikkim during this study to identify the species. Two snakes ( 1 female and 1 male) had the following characters: eight supralabials, $3^{\text {rd }}, 4^{\text {th }}$ and $5^{\text {th }}$ touching the eye, $6^{\text {th }}$ the largest; single loreal; $2+3$ temporals; 1 pre and 2 postoculars; 2 pairs of genials, anal plate entire; dorsal scales in 17-17-15 rows; coastal scales relatively larger and smoother than the mid-dorsal scales; head black with scattered yellow spots; supralabials black with yellow spots; 65 greenish yellow transverse bars in total covering both dorsal and ventral scutes including 4245 from neck to vent; bars thicker in the anterior extending to 2-4 ventrals; male - ventral scutes 217 , subcaudals 110 , snout-vent $632 \mathrm{~mm}$ and tail length $196 \mathrm{~mm}$; female - ventral 218 , subcaudals 112 , snout-vent $865 \mathrm{~mm}$ and tail length $295 \mathrm{~mm}$.

Lycodon fasciatus and D. gammiei are often confused with each other because of their similar appearance (Shaw et al. 1999; Mistry et al. 2007). Dinodon gammiei has greater number of ventral (217218 ) and subcaudal (110-112) scutes compared to L. fasciatus (201213, 74-94) respectively. Dinodon gammiei had loreals separated from the orbit by preocular (vs contact in Lycodon fasciatus), presence of yellow bands covering ventral scutes and scattered yellow markings on the head (vs lack of such colouration). However, the individuals we found in Sikkim had larger posterior genials compared to that reported by Shaw and Shebbeare (1929). Our report reaffirms the view that D. gammiei should be considered as distinct from other Lycodon and Dinodon species found within India (Mistry et al. 2007). This species has now reliably been reported from Darjeeling, West Bengal (Blanford 1878; Smith 1943; Ahmed \& Dasgupta 1992), Arunachal Pradesh (Mistry et al. 2007) and Sikkim (present study, Image 4). Dinodon gammiei was known from an altitudinal range from 1067 to $1940 m$ above mean sea level in the Eastern Himalaya (Mistry et al. 2007). Our records of the species range from 1300 to $2300 \mathrm{~m}$ in the same mountain range. This upper limit of its altitudinal distribution is now placed at $2300 \mathrm{~m}$ asl.

\section{References}

Ahmed, S. \& G. Dasgupta (1992). Reptilia. In: A.K. Ghosh (ed.). Fauna of West Bengal. Part - II, (Reptilia, Amphibia, Fishes, Hemichordata and Archaeozoology). Zoological Survey of India, Kolkata. State Fauna Series 3: $1-65$.

Blanford, W.T. (1878). Notes on reptilia from the Himalayas and Assam. Proceedings of the Asiatic Society of Bengal 6: 141-142.

Gammie, J. (1928). Reptiles, pp.188-190. In: H.H. Rishley (ed.). The Gazetter of Sikhim. Low price publication, Delhi, 397pp.

Jha, A. \& K. Thapa (2002). Reptiles and Amphibians of Sikkim. Mrs. Shila Jha, Chattisgarh, India, 100pp.

Mistry, V., G. Vogel \& F. Tillack (2007). Rediscovery of Dinodon gammiei (Blanford, 1878) (Serpentes, Colubridae), with discussion on its validity. Hamadryad 31(2): 265-273

Sanyal, D.P., S. Sur \& N.C. Gayen (2006). Reptilia. In: Fauna of Sikkim. Part - I, Vertebrates. Zoological Survey of India, Kolkata. State Fauna Series 9: 157-171

Shaw, G.E. \& E.O. Shebbeare (1929). The snakes of northern Bengal and Sikkim. Journal of the Darjeeling Natural History Society 3(3): 51-57.

Shaw, G.E., E.O. Shebbeare \& P.E. Barker (1999). The Snakes of Sikkim and Bengal. Asiatic Publishing House, Delhi, 125pp.

Smith, M.A. (1943). The fauna of British India: Reptilia and Amphibia, including the whole of the Indo-Chinese region. Vol. III - Serpentes. Taylor and Francis, London, 583pp.

Waltner, R.C. (1973). Geographical and altitudinal distribution of amphibians and reptiles in the Himalayas (Part I-IV). Cheetal 16(2): 2836.

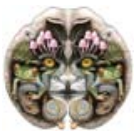

